NASA Technical Memorandum 103127

\title{
Effect of $\mathrm{KOH}$ Concentration on LEO Cycle Life of IPV Nickel-Hydrogen Flight Battery Cells
}

John J. Smithrick

Lewis Research Center

Cleveland, Ohio

and

Stephen W. Hall

Naval Weapons Support Center

Crane, Indiana

Prepared for the

25th Intersociety Energy Conversion Engineering Conference cosponsored by the AIChE, SAE, ACS, AIAA, ASME, and IEEE Reno, Nevada, August 12-17, 1990 


\section{-}


EFFECT OF KOH CONCENTRATION ON LEO CYCLE LIFE OF

IPV NICKEL-HYDROGEN FLIGHT BATTERY CELLS

\author{
John J. Smithrick \\ WASA Lewis Research Center \\ Cleveland, Ohio $4+135$
}

and

Stephen W. Hall

Nava! Weapons Support Center

Crane, Indiana +752 ?

\section{ABSTRACT}

t breakthrough in the low-earth-orbit (LEO) cycle i ife of individual pressure vessel (IPV) nichel-hydrogen battery cells was reported. The cycle life of boiler plate cells containing 26 percent potassium hydroxide (KOH) electrolyte was about to 000 LEO cycles compared to 3500 crcles for cells containing 31 percent $\mathrm{KOH}$. This test vas conducted at Hughes under a itS.t Lewis Research Center contract. The purpose for the conicact was to investigate the effect of $\mathrm{KOH}$ concentration on cycle life. The cycle regime was a stressful accelerated LEO, which consisted of a $27.5 \mathrm{~min}$ charge followed by a $17.5 \mathrm{~min}$ discharge (2x normal rate). The depth of discharge (DOD) was 80 percent. The cell temperature was maintained at $23^{\circ} \mathrm{C}$. The next step is to validate these results using $\mathrm{flight}$ hardware and a real time LEO test. NASA Lewis has a contract with the Vaval Neapons Support Center (NISC). Crane. Indiana to validate the boiler plate test results. Six t8 $t-h r$ Hughes recirculation design IPV nickel-hydrogen flight battery cells are being evaluated. Three of the cells contain 26 percent KOH (test cells), and three contain 31 percent $\mathrm{KOH}^{\mathrm{O}}$ (control cells). They are undergoing real time LEO cycle life testing. The cycle regime is a 90-min LEO orbit consisting of a 54-min charge followed by a 36 -min discharge. The depth-of-discharge is 80 percent. The cell temperature is maintained at $10{ }^{\circ} \mathrm{C}$. The cells have been cycled for over 8000 cycles in the continuing test. There have been no failures for the cells containing 26 percent $k \mathrm{kH}$. There has been two failures, however, for the cells containing 31 percent KOH.

\section{[VTRODLCTION}

The state of development of individual pressure vessel nickel-hydrogen battery cells is such that they are acceptable for Ceosynchromous orbit (GEO) applications, where not many cycles are required over the life of the battery system (1000 cycles. 10 years). There are twenty coniunication satellites in GEO using IPV nichelhydrogen batteries [1]. For the demanding lowearth-orbit applications, however, the current cycle life at moderate to deep depths-ofdischarge $(40$ to 80 percent) should be improved.

Battery cycle life has a major impact on life cycle cost for LEO applications such as
Space Station Freedom (30 year life). The primary drivers are transportation to orbit and battery cost. As part of an overall effort to improve the crole life of nickel-hydrogen battery cells the influence of $\mathrm{KOH}$ electrolyte concentration on cycle life was investigated at Hughes under a VASA Lewis contract. Hughes reported a breakthrough in LEO cycle life [2.3]. Boiler plate cells containing 26 percent $\mathrm{KOH}$ were cycled for about to 000 accelerated cucles at an 80 percent depth-of-discharge. at $23^{\circ} \mathrm{C}$. compared to 3500 crole for cells containing 31 percent koH. These results are in the process of being validated under a VASt Lewis contract with the Vaval Weapons Support Center. Crane. Indiana. Six. 48 t-hr capacity Hughes recirculation design IP: nickel-hydrogen flight cells are being evaluated Three of the cells contain 26 percent kOH (test cellsl, and the others contain 31 percent $\mathrm{KOH}$ control cells). Thev are undergoing real time LEO cycle life testing at a 80 percent depth-ofdischarge.

In this report results of characterization. storage and cucle life testing of Hughes $48 \mathrm{~A}$-hr flight cells containing 26 and 31 percent koH electrolyte are presented.

\section{EXPERIMENTAL}

\section{Test Facility}

The facility is capable of testing 45 bat tery packs with a maximum of 10 cells electrically connected in series per pack. Each pack has its own charge and discharge power supply controlled by a computer which is programmed to satisfy the particular test requirements. During testing each pack is scanned every $2.4 \mathrm{~min}$ to compare data such as voltage, temperature and pressure with programmed limits. If a paraneier is out of limit an alarm will be initiated and a message will be typed out identifying the cell and parameter. The data is recorded on a $1324 \mathrm{~B}$ disc drive and if requested can be obtained in report form. The cell temperature during a test is controlled by a recirculating cooler that circulates a solution of water and ethylene glycol through a cooling plate. 


\section{Cell Description}

Six tir Force/Hughes recirculation design IPV nickel-hydrogen flight cells manufactured by Hughes are undergoing testing. Three of the cells contain 26 percent KOH electrolyte (test cells). The other three (control cells) are identical to the test cells except they contain 31 percent KOH. Both the test and control cells contain an equal number of components. The name plate capacity is $48 \mathrm{~A}-\mathrm{hr}$. The cell is illustrated in Fig. 1. It consists of a stack of nickel electrodes, separators, hydrogen electrodes, and a gas screen assembled in a non-back-to-back electrode configuration. In this configuration electrodes of different types directly face each other. The stack is packaged in a cylindrical pressure vessel, with hemispherical end caps. This is made of Inconel 718 and lined with zirconium dioxide which serves as a wall wick. The components are shaped in a pineapple slice pattern. The electrodes are connected electrically in parallel. The separators consist of two layers of zircar. which extend beyond the electrodes to contact the wall wick Hence, the electrolyte which leaves the stack during cycling will be wicked back. The gas screens are polyproplene. The nickel electrode consist of a dry sinter plaque containing a nickel screen substrate which was electrochemically impregnated by the alcoholic Pickett process $[4]$.

\section{Measurements and Procedures}

For the experiment the quantities measured every 2.4 min for each cell during charge and discharge and their accuracies are: current $( \pm 2.0$ percent $)$, voltage $(\leq 0.001$ percent $)$, pressure $( \pm 1$ percent), and temperature $( \pm 1$ percent $)$. Charge and discharge ampere-hour capacities are calculated from current and time. Charge to discharge ratio (ampere-hours into cell on charge to ampere-hours out on discharge) is calculated from the capacities. Cell charge and discharge currents are calculated from measured, voltage across a shunt, using an integrating digital voltmeter. Cell pressure is measured using a strain gauge located on the cell dome. The temperature is measured using a thermistor, located on the center of the pressure vessel dome. The thermistor is mounted using a heat sink compound to insure good thermal contact.

Prior to cell final hydrogen gas adjustment, the nickel electrodes were positively charged, which results in a 0 psia hydrogen gas pressure. After completion of acceptance testing the cells were discharged at the $\mathrm{C} / 10$ rate $(4.8 \mathrm{~A})$ to $0.1 \mathrm{~V}$ or less. The cells were shipped to NWSC, Crane, Indiana, where they were stored trickle charged $\mathrm{C} / 200$ at $10{ }^{\circ} \mathrm{C}$ for 31 days. After storage the discharge ampere-hours capacity acceptance test was repeated. The capacity was measured after charging the cells at the $\mathrm{C} / 2$ rate $(24 \mathrm{~A})$ for $2.0 \mathrm{hr}$, then $\mathrm{C} / 10$ for $6 \mathrm{hr}$, followed by a $0.5 \mathrm{hr}$ open circuit stand. The discharge capacity was measured to $1.0 \mathrm{~V}$ at each of the following rates: $C / 2, C, 1.4$ and $2 \mathrm{C}$.
Prior to undergoing cycle life testing the capacity retention after a 72 hr open circuit stand $\left(10^{\circ} \mathrm{C}\right)$ was measured for all cells. For the cycle life test the cells were connected electrically in series to form a six cell pack. The cycle regime was a 90 min LEO orbit consisting of a 54 min charge at a constant $0.93 \mathrm{C}$ rate $(4+.7 \mathrm{~A})$ followed by a $36 \mathrm{~min}$ discharge at a $1.33 \mathrm{C}$ rate $(6+A)$. The charge to discharge ratio was $1.0+8$. The depth-of-discharge was 80 percent of name plate capacity $(48 \lambda-h r)$. During the cycle life test the cooling plate temperature was naintained at $10 \pm 2{ }^{\circ} \mathrm{C}$. Cell failure for this test was defined to occur when the discharge voltage degrades to $1.0 \mathrm{~V}$ during the course of the $36 \mathrm{~min}$ discharge.

RESLLTS AND DISCLSSION

\section{Storage Test}

The nickel-hydrogen battery could undergo a planned or unplanned storage due to delays prior to launch. What effect will this have on performance? The influence of storage (3i days. trickle charged at $\mathrm{C} / 200,10{ }^{\circ} \mathrm{C}$ ) on the capacity of the $48 t-h r$ IPV nickel-hydrogen tlight cells containing 26 and 31 percent KOH electrolyte is shown in Fig. 2. The spread in the data indicate there is no significant capacity loss after 31 days for either the 26 or 31 percent $\mathrm{kOH}$ cells.

\section{Performance Test}

A comparison of the average discharge voltage ( 3 cells) as a function of time for the cells containing 25 and 31 percent $\mathrm{KOH}$ was made and is shown in Fig. 3. The voltage for the 26 percent $\mathrm{KOH}$ cells is higher than for the 31 percent $\mathrm{kOH}$ cells up to about an 82 percent depth-ofdischarge. The discharge rate was $1 .+\mathrm{C}(67,2 \mathrm{~A})$ and the cell temperature was maintained at $10{ }^{\circ} \mathrm{C}$. The ampere hour capacity for these cells is shown in table I $\left(1.4 \mathrm{C}, 10^{\circ} \mathrm{C}\right)$. The capacity on the average for the 26 percent $\mathrm{KOH}$ cells was about 10 percent lower than the 31 percent KOH cells. This relatively small decrease in initial capacity is traded for a significant increase in cycle life. It should be noted that the data in table I is for a 100 percent DOD. In an actual application the DOD will be much less, for instance the DOD for Space Station Freedom will be about 35 percent. At this DOD the portion of the curve in Fig. 3 being operated at is where the cells containing 26 percent kOH have a higher discharge voltage, and still have adequate capacity reserve.

\section{Cycle Test}

The influence of LEO cycling at 80 percent DOD on the end of discharge voltage for the $48 \mathrm{~A}-\mathrm{hr}$ IPV nickel-hydrogen flight cells contain. ing 26 percent KOH is summarized in Fig. 4. Af ter about 8000 cycles there have been no cell failure. The end of discharge voltage is increasing with cycling for two of the three cells 
This trend is in agreement with the observation for boiler plate cells (26 percent $\mathrm{KOH}$ ) cycled at Hughes [2.3]. Hong $\mathrm{Lim}$ of Hughes at tributed this voltage shift to a crystallographic change of active material [5]. Camma $\mathrm{NiOOH}$ to beta in 26 percent $\mathrm{KOH}$. Beta nickel hydroxide has a lower capacity but longer cycle life. The influence of cycling on the end of charge pressure for the 26 percent KOH cells is shown in Fig. 5. The pressure increase, on the average is about 26 percent at cycle 7700 . This pressure increase could be indicative of nickel plaque corrosion, which converts nickel to active material. The increase in pressure will result in a shift in the beginning of life state-of-charge versus pressure curve.

The influence of LEO cycling at 80 percent $D O D$ on the end of discharge voltage for the cells containing 31 percent $\mathrm{KOH}$ is shown in Fig. 6. Two of the three cells failed. Cell 1 failed at cycle 3729 and cell 2 failed at cycle 4165 . Cell 3 did not fail and is still cycling. The failure for each cell was characterized by degradation of discharge voltage to $1.0 \mathrm{~V}$. Neither cell failed due to an electrical short. A comparison of the discharge curve at the beginning and end of life for cell 1 which failed at cycle 3729 is shown in Fig. 7. This information also shows a voltage degradation. For this cell the ampere-hour capacity decrease $\left(1.4 \mathrm{C}\right.$ rate, $\left.10^{\circ} \mathrm{C}\right)$ was about 33 percent and for cell 2 it also was about 33 percent. The influence of cycling on the end of charge pressure for the cells containing 31 percent $\mathrm{KOH}$ is shown in Fig. 8. The pressure change for the two failed cells can be correlated with the discharge voltage change due to cycling. The pressure increase, for the cell which did not fail is about 27 percent at cycle 7700 . This increase is about the same as for the 26 percent $\mathrm{KOH}$ cells. The failed cells are in the process of undergoing teardown and failure analysis. To put the cycle life date ( 26 percent $\mathrm{KOH}$ ) in perspective a comparison was made to recent NWSC, Crane test results for Yardney and Cates nickel-hydrogen cells (31 percent KOH). This comparison is shown in Fig. 9. The first Yardney cell failed at cycle 2488,100 percent failed by cycle 2615 . The first Gates cell failed at cycle 1702, 80 percent failed by cycle 3561 , and 100 percent failed by cycle 4919. For the Hughes 26 percent $\mathrm{KOH}$ cells none failed after 8000 cycles even though they are being cycled at a more stressful DOO ( 80 percent name plate capacity, 72 percent actual). The Yardney and Gates cells were cycled at a shallower, less stressful DOD (60 percent based on actual capacity).

\section{CONCLUDING REMARKS}

A breakthrough in the low-earth-orbit cycle life of individual pressure vessel nickel-hydrogen battery cells was reported. The cycle life of boiler plate cells containing 26 percent $\mathrm{KOH}$ electrolyte was about 40000 accelerated LEO cycles at 80 percent DOD compared to 3500 cycles for cells containing 31 percent $\mathrm{KOH}$. Results of the boiler plate cell test are in the process of being validated at NWSC, Crane. Forty-eight A-hr flight cells containing 26 and 31 percent $\mathrm{kOH}$ are undergoing real time LEO cycle life testing at an 80 percent $\mathrm{DOD}, 10^{\circ} \mathrm{C}$. The three cells containing 26 percent $\mathrm{KOH}$ have been cycled for over 8000 cycles with no cell failure. Two of the three cells containing 31 percent $K O H$ failed (cycle 3729 and 4165 ) and are in the process of undergoing teardown and failure analysis.

\section{REFERENCES}

1. Miller, L.: The Vi-H2 Battery System: $t$ Space Flight Application Summary. Proceedings of the 23 rd Intersociety Energy Conversion Engineering Conference. vol. 2 . ASME, 1988. pp. $489-492$.

2. Lim, H.S.; and Verzwyvelt, S.A.: $\mathrm{KOH}$ Concentration Effect on Cycle Life of Nickel-Hydrogen Cells. III. Cycle Life Test. J. Power Sources, vol. 22, no. 3-4. Mar.-Apr. 1988, pp. 213-220.

3. Lim, H.S.: and Verzwyelt. S.A.: KOH Concentration Effect on the Cucle Life of Nickel-Hydrogen Cells. IV. Results of Failure Analysis. 3. Power Sources. in Press. 1990.

4. Pickett. D.F.: Preparation of Vickel Electrodes. U.S. Patent 3.827,911, lug. 1974.

5. Lim, H.S.: and Verzwyvelt, S.A.: Electrochemical Behavior of Heavily Cvcled Nickel Electrodes in $\mathrm{Ni}-\mathrm{H} 2$ cells Containing Electrolytes of Various KOH Concentrations. Presented at the $176 \mathrm{th}$ Keeting of the Electrochemical Society, Hollywood, FL, Oct. 15-20, 1989 (in Press, 1990).

TABLE I . - CAPACITY OF HLGHES

FLIGHT CELLS CONTAINING

26 AND 31 PERCENT

KOH ELECTROLYTE

\begin{tabular}{|c|c|c|}
\hline Cell & $\begin{array}{c}\text { Capacity, } \\
\text { t-hr }\end{array}$ & $\begin{array}{c}\mathrm{KOH} \\
\text { conc }, \\
\text { percent }\end{array}$ \\
\hline 1 & 59.0 & 31 \\
2 & 59.9 & 31 \\
3 & 59.0 & 31 \\
4 & 53.8 & 26 \\
5 & 53.2 & 26 \\
6 & 52.3 & 26 \\
\hline
\end{tabular}

aDischarge at $1.4 \mathrm{C}$ rate, $10^{\circ} \mathrm{C}$. 




FIGURE 1, - ILLUSTRATION OF HUGHES RECIRCULATION STACK INDIVIDUAL PRESSURE VESSEL NICKEL-HYDROGEN CELL.

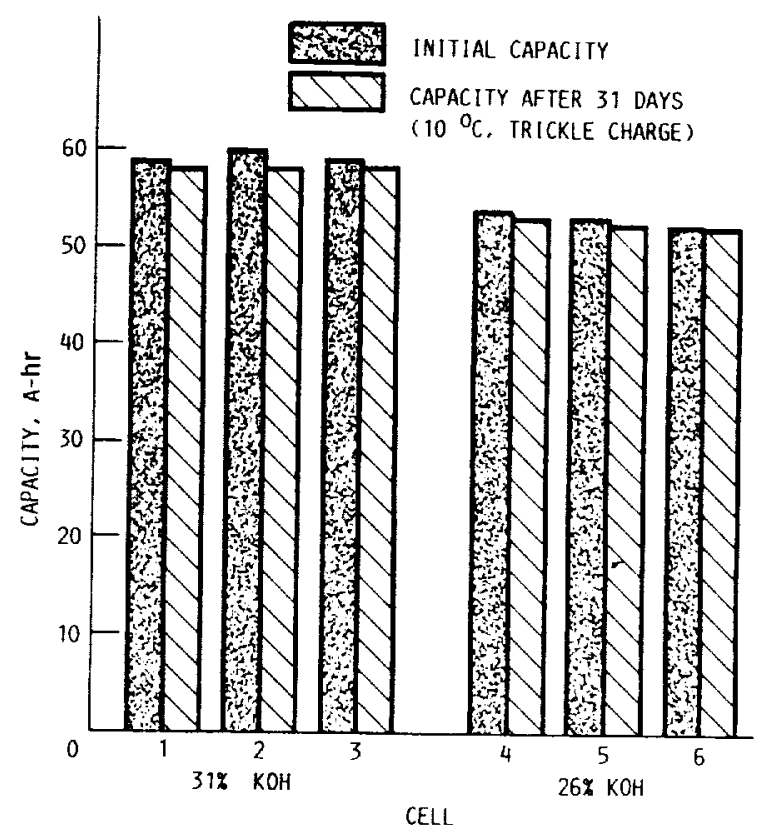

FIGURE 2. - EFFECT OF STORAGE ON CAPACITY OF $48 \mathrm{~A}$-hr HUGHES IPV NI/H2 FLIGHT CELIS.



FIGURE 3. - COMPARISON OF HUGHES $48 \mathrm{~A}$-hr IPV $\mathrm{Ni} / \mathrm{H}_{2}$ FLIGHT CELLS CONTAINING 26\% AND $31 \% \mathrm{KOH}$ ELECTROLYTE.

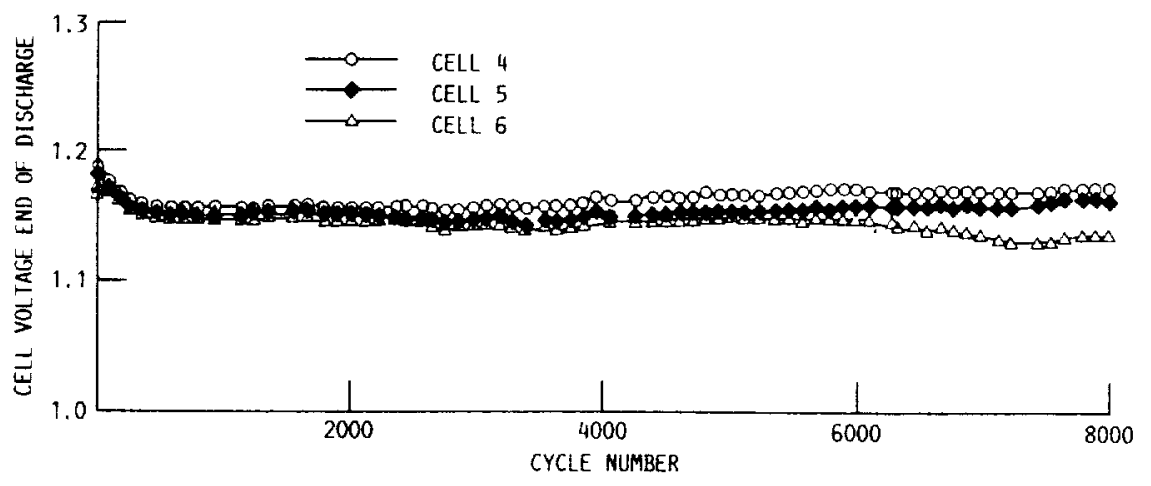

FIGURE 4. - EFFECT OF LEO CYCLING AT $80 \%$ DOD ON HUGHES FLIGHT CELLS CONTAINING 26\% KOH ELECTROLYTE, $10{ }^{\circ} \mathrm{C}$ 


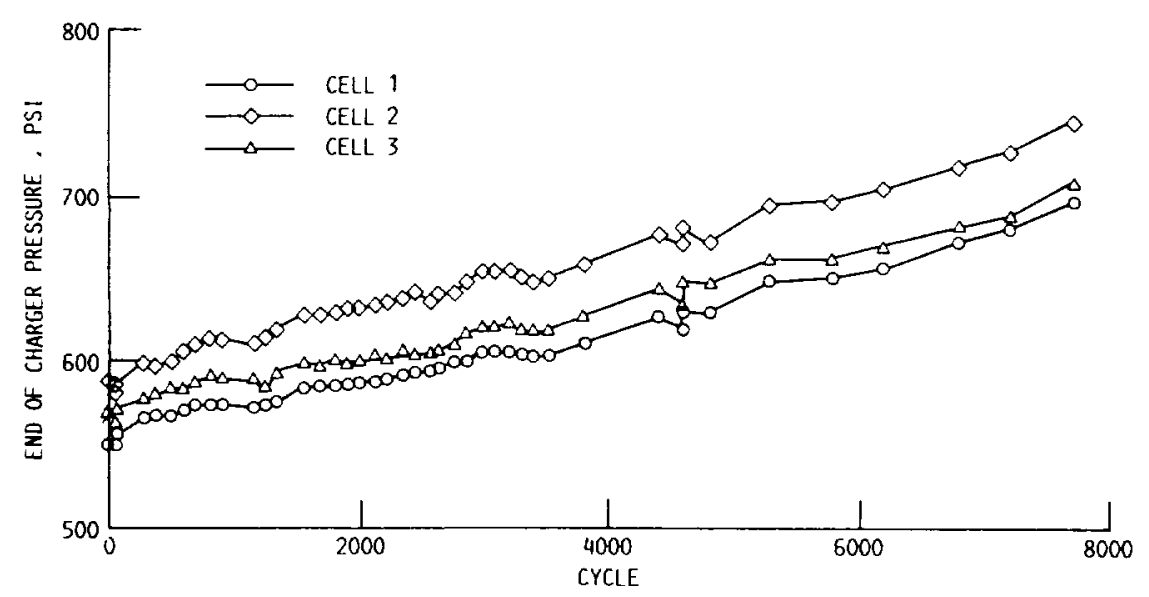

FIGURE 5. - EFFECT OF CYCLING AT $80 \pi$ DOD ON HUGHES FLIGHT CELLS CONTAINING $26 \%$ $\mathrm{KOH}, 10^{\circ} \mathrm{C}$.

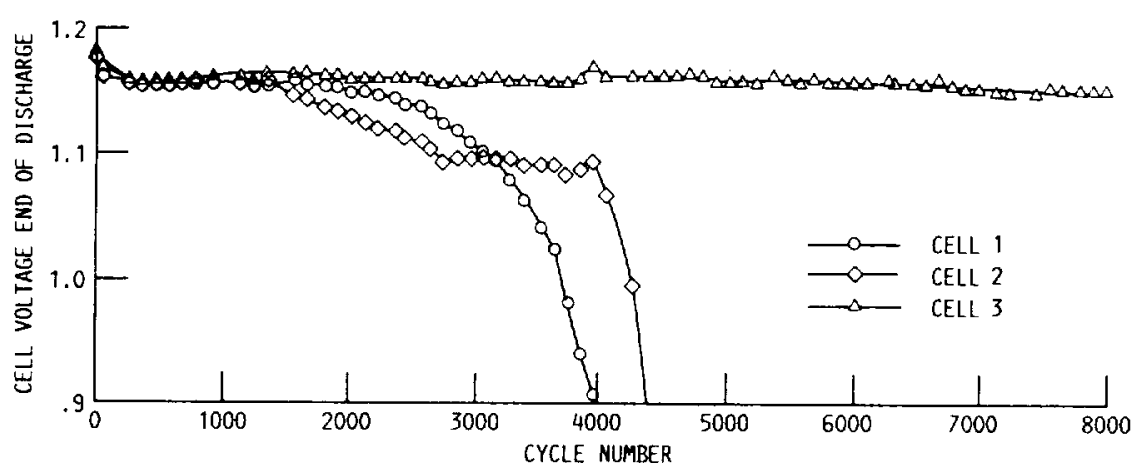

FIGURE 6. - EFFECT OF LEO CYCLING AT 80\% DOD ON HUGHES FLIGHT CELLS CONTAINING 31\% KOH ELECTRLOYTE, $10^{\circ} \mathrm{C}$.

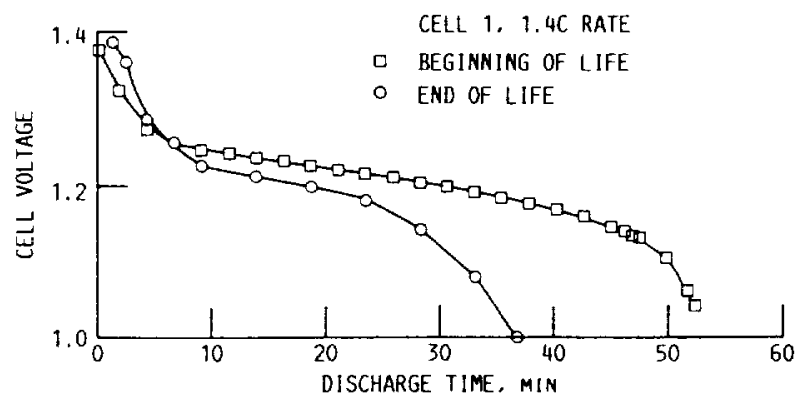

FIGURE 7. - CELL VOL TAGE FOR HUGHES $48 \mathrm{~A}-\mathrm{hr} I \mathrm{PV} \mathrm{NI} / \mathrm{H}_{2}$ FLIGHT CELL CONTAINING 31\% KOH ELECTROLYTE. 


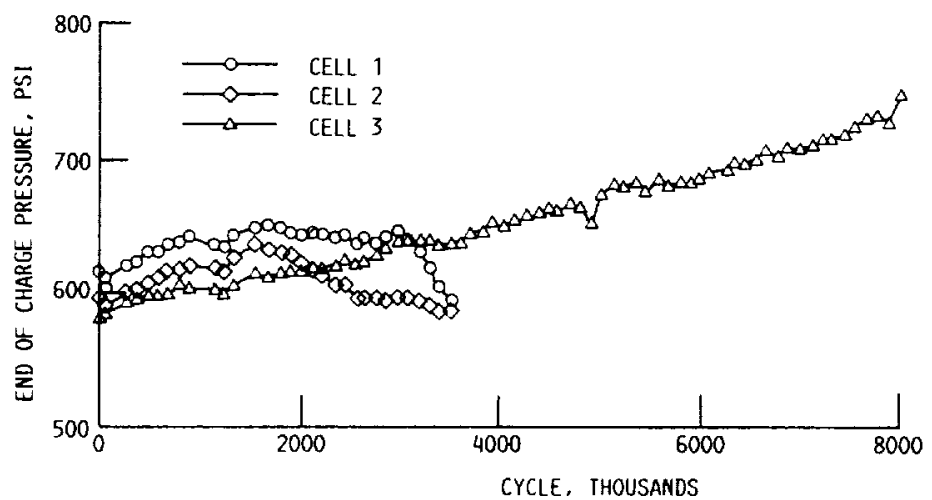

FIGURE 8. - EFFECT OF CYCLING AT $80 \%$ DOD ON HUGHES NI/H 2 FLIGHT TELLS CONTAINING $31 \% \mathrm{KOH}, 10^{\circ} \mathrm{C}$.

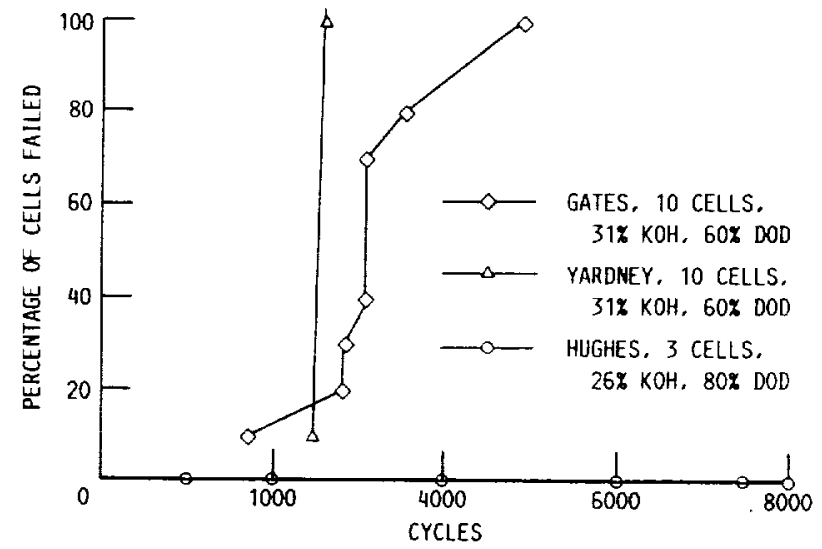

FIGURE 9. - COMPARISON OF CYCLE LIFE FOR HUGHES, GATES, AND YARDNEY IPV Ni/H2 FLIGHT CELLS. 


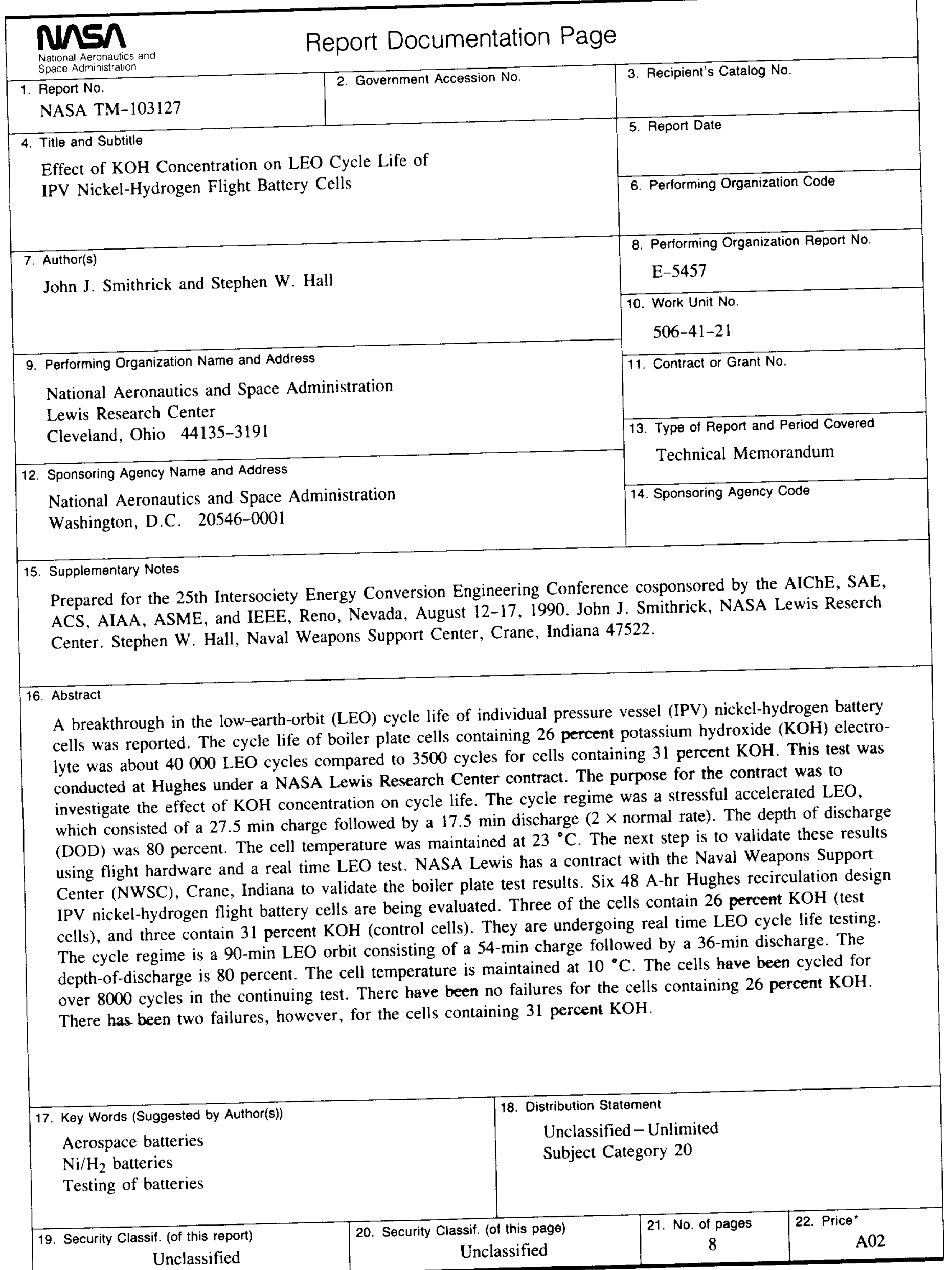




\author{
-
}


(1) 
National Aeronautics and Space Administration

Lewis Research Center

Cleveland, Ohio 44135

Offlclal Buainess

Penalty for Private Use $\$ 300$
FOURTH CLASS MAIL

||||

ADDRESS CORRECTION REQUESTED

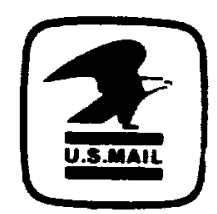

Postage and Fees Pard National Aeronautics an Spact Admistratuon NASA 451 